\title{
THE EFFECT OF PRINCIPAL'S LEADERSHIP ON THE PERFORMANCE OF SOCIAL SCIENCE TEACHERS
}

\author{
M. Yogi Riyantama Isjoni ${ }^{1}$, Indra Primahardani ${ }^{2}$, Asyrul Fikri ${ }^{3}$ \\ ${ }^{1,2,3}$ Faculty of Teachers Training and Education, Universitas Riau, Indonesia
}

Corresponding author: m.yogi@lecturer.unri.ac.id

\begin{abstract}
Article Info
Abstract

Received: 07 September 2021

The purpose of this study was to determine the effect of principal's

Accepted: 25 October 2021

Published: 26 October 2021 leadership on social science teachers' performance. The research was conducted in Pelalawan Regency taking Social Science teachers in Pelalawan Regency as the research subjects. The method used was a survey with quantitative techniques. The research sample was 150

\section{Keywords:}

Leadership; principal's leadership; social science teachers' performance

Pelalawan Regency teachers selected using random sampling technique. The instrument used to collect data was a set of questionnaires used to quantify the school principal leadership level. Data of teachers' performance were gathered from the teachers' competency test (UKG) data. The results of this study indicate that there is a significant and positive influence of the principal's leadership on the performance of social science teachers at SMPN Pelalawan. The results of this study are expected to be useful for the improvement of the performance of school principals and social science teachers in Pelalawan Regency.
\end{abstract}

\section{INTRODUCTION}

Teachers are the leading figures in changing the educational paradigm at schools. They are one of the important elements for the success of achieving the school's vision and missions. Teachers are expected to work enthusiastically, full of initiative, full of passion and with a high will. The high work spirit of the teachers is manifested in the form of creativity and initiative in organizing the learning process. If all of the aspects are well done, they will produce teachers' good performance as well.

International Journal of Educational Best Practices (IJEBP)

Vol.5 No.2 October 2021

ISSN: $2581-0847$

DOI: 10.32851/ijebp.v5n2.p223-230 
Teachers' performance is closely related to how to assess a teacher's work so it is necessary to apply assessment standards. Teacher performance is one of the keys to successful implementation of learning in schools. Learning is the key to education. Teacher professionalism in work is an obligation for every teacher in school.

One of the high teacher performances is shown by teacher professionalism which consists of mastering four competencies including professional, pedagogical, personality and social competencies. For this reason, performance plays an important role in achieving teaching goals so that they can be achieved optimally.

The problem is that there are still teachers who teach inappropriately in their fields so that they feel that they are lacking in professional competence. Based on the initial competency test of teachers in 2012 nationally, the average values of the initial competency test for Kindergarten, junior high school, senior high school, and vocational high school teachers are $58.87,36.86,46.15,51.35$, and 50.02 respectively (Ester, 2012)

Supardi (2013) explains that performance is the result of work that has been achieved by someone in an organization to achieve goals based on standardization or size and time that is adjusted to the type of work and in accordance with established ethical norms. Teachers' performance in a school plays a role in the success of achieving school goals. The better the quality and performance of a teacher, the greater his role in achieving educational goals. Therefore, the teacher is an important factor in the implementation of education in schools. This is because the teacher is the party who interacts directly with the students.

In addition, Casio in Supardi (2013) mentions that there are many factors that affect a person's performance, including: (1) participation of Human Resources (HR), (2) career development, (3) communication, occupational health and safety, (4) 4 completion conflict, (5) good incentives, and (6) pride. Furthermore, Supardi (2013) explains that there are other aspects that can be used to assess work performance or performance including: (1) work ability, (2) craft, (3) discipline, (4) work relations, (5) initiative, and (6) leadership.

Teachers' performance is influenced by many factors, either directly or indirectly. Some of them are leadership styles and behaviors, in this case the principal, influence and leadership power, motivation, trust, and decision making. Mulyasa (2003) explained that the principal is an educational leader at the education unit level who must have a strong leadership base. For this reason, every principal must understand the key to leadership success which includes the importance of principal leadership.

Meanwhile, Wahjosumidjo (2005) defines the principal as a functional teacher who is given the task of leading a school where the teaching and learning process is held, or a place where

International Journal of Educational Best Practices (IJEBP)

Vol.5 No.2 October 2021

ISSN: 2581-0847

DOI: 10.32851/ijebp.v5n2.p223-230 
there is interaction between teachers giving lessons and students receiving lessons. The word lead in means the ability to mobilize all available resources in the school so that they can be utilized optimally to achieve the goals set. The principal's leadership in leading and managing is one of the keys to the success of achieving school goals.

The principal is actually an ordinary teacher, who is given the task of leading a school, where the teaching and learning process is held. The principal has a heavy, but noble responsibility. As an official, the principal must comply with the existing rules. To do his or her job, the principal must have a good personality, adhere to good religious teachings, have noble character and be free from despicable actions. Principals in their duties must understand management. At least they can plan, organize, lead and control members, empower various organizational resources and conduct evaluations in achieving school goals that have been set.

The principal is a leadership position that cannot be filled by people without being based on consideration. Whoever will be appointed as principal must be determined through certain procedures and requirements such as educational background, experience, age, rank and integrity. Therefore, the principal is essentially a formal official because his appointment is through a process and procedure based on applicable regulations.

Some phenomena in the field indicate low performance of social science teachers at the Pelalawan District Junior High School. This is evidenced by the results of interviews and discussions with school principals, vice principals and students. The authors collected the information so that it is reasonable to suspect that some social science teachers have poor performance at schools. This poor performance can also be seen on the basis of the results of Teacher Competency Test (UKG) for Riau teachers in 2015. The data shows that the teachers' average score was below the national standard (53.02). The test itself tested the teachers' competency across two core competencies: professional and pedagogical competencies. The low scores indicate that many teachers are still underperform in conducting teaching and learning process at schools.

Before the UKG, the government also assessed teachers' performance using Teacher Performance Assessment (PKG) system. Some aspects measured in this assessment system include the for professional teachers' competencies (professional, pedagogical, social, and personal competencies), the implementation of the learning and guidance process and some relevant additional tasks for teachers' roles and responsibilities at schools. The results of this PKG was also not satisfactory enough for Riau teachers' performance.

Some teachers do not show maximum performance in fulfilling their teaching duties with a set number of teaching hours. Some teachers are still talking and chitchatting with their colleagues in the office when they are supposed to have been in the classrooms. Some other

International Journal of Educational Best Practices (IJEBP)

Vol.5 No.2 October 2021

ISSN: 2581-0847

DOI: 10.32851/ijebp.v5n2.p223-230 
teachers do not have the preparation of learning materials, so students are assigned to do activities such as taking notes from the blackboard while the teacher goes to have breakfast in the canteen. Another problem is that the teachers are not creative so that the learning process always monotonous without using media and classes are always classical models. They rarely motivate students to have a better spirit of learning.

Besides, teachers rarely evaluate and follow up on evaluations in order to be able to record children who understand the material and children who are lacking in learning, assignments given to students are less challenging and monotonous, lack of quality of questions given to students so students are not interested in answering teacher questions, favoritism to children students, and the way the teacher answers, questions from students are not polite, the writing on the blackboard is too small so it is difficult for students to see the writing, this causes students to compete to see the writing resulting in a noisy classroom atmosphere. The worst thing is that it results in low achievement of the students in mastering the learning objectives. Based on the problems as previously discussed, this study investigates the effect of school principal leadership on the performance of social science teachers at SMPN Pelalawan Regency

\section{RESEARCH METHODS}

The research was carried out in Pelalawan Regency start from February to May 2021. The research instrument used for data collection is a questionnaire. In this study there are two research variables, namely one independent variable, which is the principal's leadership (X) and a dependent variable namely social science teachers' performance (Y).

The population in this study were social science teachers at public junior high schools in Langgam, Pangkalan Kerinci and Bandar Sekijang districts, Pelalawan Regency with a total population of 238 teachers. Then, 150 teachers were selected as samples using simple random sampling technique

The preparation of the measuring instrument started with the creation of a table of specifications for the scale of the principal's leadership and teacher performance indicators. Items include positive statements (favorable) and negative statements (unfavorable). The alternatives provided by the researcher in this scale are Always (SL), Often (SR), Sometimes (KK), Rarely (JR), and Never (TP), with a value scale of 5, 4, 3, 2, and 1 . Then the answers to the negative items are Always (SL), Often (SR), Sometimes (KK), Rarely (JR), and Never (TP), with a value scale of $1,2,3,4$, and 5 .

International Journal of Educational Best Practices (IJEBP)

Vol.5 No.2 October 2021

ISSN: 2581-0847

DOI: 10.32851/ijebp.v5n2.p223-230 
Other than that questionnaire, the UKG teacher's score for social science were also used for teachers' performance data. The data analysis technique used in this research is descriptive statistical analysis and inferential statistical analysis. Data processing for descriptive statistical analysis in this study using Microsoft Excel and SPSS version 17 for Windows.

The data analysis technique used in this research is descriptive statistical analysis and inferential statistical analysis. Data processing for descriptive statistical analysis in this study was done using Microsoft Excel and SPSS version 17 for Windows.

\section{RESULTS AND DISCUSSION}

\section{Results}

It is found that the correlation coefficient between the principal's leadership and teachers' performance is 0.709 . The coefficient of determination $(\mathrm{r} 2)=(0.709) 2$ is 0.503 or $50.3 \%$, meaning that the magnitude of the influence of the principal's leadership on teachers' performance is $50.3 \%$ while the rest is influenced by other factors. This means that the variable $\mathrm{X}$ has a high enough influence on the variable $\mathrm{Y}$.

For the influence of the principal's leadership on teachers' performance, the regression coefficient formed is 0.709 which means that the strength of the influence between principals' leadership on teachers' performance is strong. From the calculation of the coefficient of determination obtained rx.y $=0.709 \mathrm{a}=0.709$ or $70.9 \%$. This means that $70.9 \%$ of the variance in teachers' performance can be explained by the principal's leadership through the regression equation $\mathrm{Y}=33.768+0.511 \mathrm{X} 1$. The regression equation $\mathrm{Y}=33.768+0.511 \mathrm{X} 1$ means that every increase in one unit of the principal's leadership score is followed by an increase in teachers' performance scores of 0.511 at a constant 33.768 .

To test the significance of the regression between the principal's leadership (X) on teachers' performance (Y), the t-test formula was used. The value of t count is 12.231 . While the value of the $\mathrm{t}$ table to test the two parties with $\mathrm{dk}=147,=0.05$, the $\mathrm{t}$ table value is 1.655 . Because $12.231>1.655 \mathrm{t}$ arithmetic $=12.231>\mathrm{t}$ table 1.655 .

It can be concluded that there is a significant relationship, thus the null hypothesis (H0) is rejected, otherwise the alternative $(\mathrm{Ha})$ is accepted. The conclusion is that there is a significant influence between the principal's leadership (x) on teachers' performance (Y)

International Journal of Educational Best Practices (IJEBP)

Vol.5 No.2 October 2021

ISSN: 2581-0847

DOI: 10.32851/ijebp.v5n2.p223-230 
Then from the results of F count $149.595>\mathrm{F}$ table 3.06, with a significance level of 0.05 , then $\mathrm{HO}$ is rejected. Thus, the first hypothesis in this study is accepted, which means that there is a significant influence between the principal's leadership on teachers' performance.

The influence of the principal's leadership on teachers' performance shows a positive and significant regression coefficient. This means that if the principal's leadership is good, the teacher's performance will be better or increased.

These results are in accordance with the research conducted by Sumarno (2009). The results showed that there was a positive and significant influence of principal's leadership on the performance of elementary school teachers in Palalawan District by $25.8 \%$. Professionalism had a positive and significant effect on teachers' performance with a coefficient of determination of $39.4 \%$. The results of multiple regression analysis show that there is a positive and significant influence of principal leadership on the social science teachers' performance.

The results of the study are in line with some othe studies indicating that the factors that affect teachers' performance are both internal and external factors. The internal factors of teachers' performance include abilities, skills, personality, perceptions, motivation to become teachers, experience field and family background. While the external factors of teachers' performance are factors that come from outside the teacher that can affect their performance, which include salary, facilities and infrastructure, physical work environment, and principal leadership.

Thus, the better leadership of the principal in the SMPN Pelalawan, the better the teacher's performance will be. This is evidenced by the results of the regression analysis that the principal's leadership coefficient is positive. These results are in accordance with research conducted by Astuti (2014), the results of the study show that teachers' performance is influenced by the leadership of the principal by $18.8 \%$. Performance is influenced by social science Teacher Competence by $24.9 \%$ and the remaining $75.1 \%$ is influenced by other factors not examined in this study. $56.2 \%$ of teacher professionalism on the performance of elementary school teachers in Paguyangan District with a coefficient of determination of $43.8 \%$.

Then, the results of this study are also reinforced by the theory of Tehsen and Ul Hadi (2015) several factors that influence teachers' performance are: (1) work environment, (2) work motivation, (3) principal's leadership style, (4) behavior, (5) attitudes, and (6) relationships with fellow teachers. Syadam (1996) stated that the factors that influence the performance of a teacher in carrying out his work are: (1) education level, (2) work experience, (3) work environment, (4) supporting equipment or facilities, (5) leadership, and (6) the teacher's own work motivation. Wibowo (2007) says that teachers' performance is influenced by

International Journal of Educational Best Practices (IJEBP)

Vol.5 No.2 October 2021

ISSN: 2581-0847

DOI: 10.32851/ijebp.v5n2.p223-230 
knowledge, ability, attitude, work style, personality, interests, basic values, beliefs and leadership style of the principal.

A principal must have strong leadership. If the leadership of the principal continues to be honed and improved, it will automatically have a positive effect on teachers' performance in schools. Then, with the encouragement of strong work motivation, it can improve the performance of teachers in schools, if it continues to be updated and improved, it will also become a factor that makes a real contribution to the performance of teachers in the school. It can be concluded that these two aspects, namely the principal's leadership and work motivation, are the dominant factors determining the achievement of good teachers' performance.

\section{CONCLUSION}

It can be concluded that there is a positive and significant influence between the principal's leadership on the performance of social science teachers at public junior high schools in Pelalawan Regency. This means that if the principal's leadership is improved, the teacher's performance will increase. On the contrary, the lower the principal's leadership, the lower the teacher's performance. Thus, it can be seen that the hypothesis proposed by the research is acceptable, namely the principal's leadership has a significant influence on teachers' performance.

\section{REFERENCES}

Astuti, T. P. (2014). Perbedaan literasi emergen anak taman kanak-kanak di daerah perkotaan dan pinggiran. Jurnal Psikologi, 13(2), 107-119.

Colquitt, L., \& Wesson, O. B. (2009). Improving Performance and Commitment in the workplace. Florida: McGraw-Hill Irwin, 2.

Ester L. N. (2012, February 10 ). Uji Kompetensi Awal Bagi Guru Segera Dilaksanakan. Kompas.com. Retrieved https://money.kompas.com/read/2012/02/10/21513911/ Edukasi News

H. John, B. (2013). Human Resource Management: An Experiential Approach. New York: McGraw-Hill Irwin.

International Journal of Educational Best Practices (IJEBP)

Vol.5 No.2 October 2021

ISSN: 2581-0847

DOI: 10.32851/ijebp.v5n2.p223-230 
Michael, A. (2008). Performance Management: By Strategies and Practical Guidelines. United States : Thomson-shore, inc.

Mullins, L. J. (2005). Management and Organizational Behavior. Edinbiurgh Gate, Prentice Hall Financial Times.

Mulyasa, E. (2003). Menjadi kepala sekolah profesional dalam konteks menyukseskan MBS dan KBK.

Newstrom. J. W. (2001). Behavior: Human Behavior at Work New York: McGraw-Hill International.

Rivai, V. \& Sylviana, M. (2009). Education Management: Analysis of Theory and Practice. Jakarta: Rajawali Press.

Robbins, S. P. \& Judge. T. A. (2013). Organizational behavior (Vol. 4). New Jersey: Pearson Education.

Siswanto, B. (1989). Manajemen tenaga kerja. Bandung: Sinar Baru.

Sumarno. (2009). Pengaruh Kepemimpinan Kepala Sekolah dan Profesionalisme Guru Terhadap Kinerja Guru Sekolah Dasar Negeri di Kecamatan Paguyangan Kabupaten Brebes (Tesis master, Universitas Negeri Semarang, Indonesia). Indonesia.

Supardi. (2013) Kinerja Guru. Jakarta: PT Rajagrafindo Persada.

Syadam, Gouzali. (1996). Manajemen Sumber Daya Manusia (Human Resources Management) Suatu Pendekatan Mikro (Dalam Tanya Jawab). Jakarta: Djambatan

Syafrudin. (2007). Integrated Quality Management in Education. Jakarta: Grasindo.

Tehseen, S., \& Ul Hadi, N. (2015). Factors influencing teachers' performance and retention. Mediterranean Journal of Social Sciences, 6(1), 233-244. https://doi.org/10.5901/mjss.2015.v6n1p233

Wahjosumidjo. (2005). Principal Leadership. Jakarta: PT Raja Grafindo Persada

Wibowo. (2007). Manajemen Kinerja. Jakarta: Balai Aksara

International Journal of Educational Best Practices (IJEBP)

Vol.5 No.2 October 2021

ISSN: 2581-0847

DOI: 10.32851/ijebp.v5n2.p223-230 